\author{
Azem Hajdari ${ }^{1}$ \\ Professor of Faculty of Law, University of Prishtina, Prishtina, Kosovo \\ Albulena Hajdari ${ }^{2}$ \\ Professor of Faculty of Law, College of Iliria, Kosovo
}

\title{
THE SPECIFICS OF THE ILLEGAL DRUG TRAFFICKING IN KOSOVO
}

UDK: 339.7:613.83 (497.115)

DOI: $10.31141 /$ zrpfs.2020.57.135.239

Pregledni znanstveni rad

Primljeno: 1. ožujka 2019.

\begin{abstract}
Object of handling in this scientific paper are criminal offences of narcotics trafficking in the Republic of Kosovo. According to data included in this paper the trafficking of narcotics constitutes a concerning phenomenon. The concern about this type of criminality is linked to a relatively high degree of their presence in Kosovo society. The research shed light about the fact that Kosovo is an important link for international drug traffickers. All this, due to geographic position of country because of the fact that in Kosovo there are over 25,000 drug users, but likewise because of the fact that over last two decades there has been a trend of continuous growth of drug process cultivation. Criminal offences of narcotics trafficking manifest numerous individual, family and social consequences. This criminal phenomenon is also damaging Kosovo's image in international terms. Kosovo is facing numerous challenges and problems in combating criminality, especially those related to narcotics. In this scientific paper has been indicated the Kosovo courts activities in combating criminal offences of narcotics trafficking as well as are given various ideas in terms of how it should be advances courts performance in combating this criminal phenomenon. For preparation of this scientific paper we have used legal, comparative, descriptive, survey and statistical methods.
\end{abstract}

Key words: Trafficking, narcotics, court, perpetrator, punishment.

\section{INTRODUCTION}

Criminal offenses of narcotics trafficking represent a kind in itself of criminal offences. In Kosovo, during the researching period of time (2013 - 2017) have marked a relatively high presence. They have been committed by individual and group perpetrators. Criminal offences of narcotics trafficking can only be committed by intent and in order to realize unlawful wealth benefit. For commission of criminal offences of narcotics trafficking the Kosovo lawmaker has foreseen the punishment by fine and imprisonment up to fifteen (15) years. These criminal offences can be committed in a number of manners and they express numerous individual,

\footnotetext{
1 Azem Hajdari, E-mail: azem.hajdari@uni-pr.edu

2 Albulena Hajdari, E-mail: albulenahajdari@gmail.com
} 
family and social consequences of health, social, and misbehavior character. These consequences are reflected in damaging people's health (narcotics consumers), isolation of perpetrators and their families (in schools and neighborhoods), divorce, damage to the international image of state. Modest results of this scientific paper indicate that during the period of time 2013-2017, have been submitted 2987 indictments and have been convicted 1950 persons. This discrepancy between these figures lies in fact that in relation to procedure of handling these criminal offences have resulted in dismissal of a considerable number of indictments and have come to statutory limitation of criminal prosecution of a considerable number of court cases. Trafficking materials were all sorts of drugs. Conducted researches prove the fact that Kosovo during the researching period of time was a country of origin, as well as transitory and destined country for narcotics trafficking. Despite these facts, is considered that Kosovo Courts against the perpetrators of criminal offenses of narcotics trafficking has applied very mitigating criminal policy. Therefore, a successful fight against these criminal offences requires the aggravation of criminal policy and raise of responsibility and professionalism level of prosecution and adjudication professionals, as well as blockage of external interventions in criminal justice system bodies' work.

\section{VARIOUS CRIMINAL LEGAL ASPECTS OF CRIMINAL OFFENCES OF NARCOTICS TRAFFICKING IN KOSOVO}

\section{Meaning and constituent elements}

Narcotics are natural and synthetic substances which mainly affect the central nervous system of the human being by causing an unusual spiritual condition and then creating a stable addiction on demand of continuous consumption (Salihu, Zhitija, Hasani, 2014, pg.752). Since consumption, production, processing and trade with narcotics poses a serious threat to the health and well-being of people, to economic and cultural development, as well as to the stability and security of country and beyond (Pragnesh, Gunvanti, Sangita, Alshish, 2012, pg. 2 - 3), narcotics trafficking is considered to be a criminal activity of an international character (Dundović, 1998, pg.9). Narcotics trafficking has been banned by a number of international conventionsKambovski, 2011, pg. 830) and domestic criminal legislation of states. Kosovo lawmaker addressed the criminal offenses of narcotics trafficking in a separate chapter (Chapter XXIII), which includes ten types of these criminal offenses.

The definition of criminal offences of narcotics trafficking constitutes a complicated matter. This due to the fact that criminal legislations of contemporary states do not provide a full definition of these criminal offences, but also because of the fact that within these legislations exist more than one criminal offence incriminating 
actions (but also omissions) related to narcotics, including their trafficking. ${ }^{3}$ Despite this, according to the Criminal Code ${ }^{4}$ and criminal legal doctrine of Kosovo, the criminal offenses of narcotics trafficking consist in undertaking illegal (unauthorized) actions through which is possible to produce (cultivate), process, possess, purchase, distribute, sell, transport, delivery and mediation for distribution, sale and supply of narcotics, export and import of narcotics, and organization, direction and financing of activities referring to production, processing, possession, purchase and delivery for sale of narcotics (Salihu, 2009, pg.290). Criminal offence of narcotic trafficking is considered to exist despite of the fact whether incriminating actions related to narcotics manifest extent only within the territory of a state or even beyond that territory.

Criminal offences of narcotics trafficking consist of three essential elements such as: actions, illegal means and purpose.

1. Actions. - Action as an element of criminal offences of narcotics trafficking may have to deal with: production (cultivation), processing, possession and purchase of narcotics, distribution, sale, transportation, delivery and mediation for distribution, sale and delivery in narcotics sales, or export or import of narcotics, as well as organizing, directing and financing activities referring to the possession, purchase and sale of narcotics.

2. Illegal means. - This element of criminal offenses of narcotics trafficking consists in undertaking any of the above mentioned actions without having proper (legal) authorization (Elezi, 1999, pg. 115). This means that if the purchase or possession for the purpose of sale or distribution of narcotics is done with authorization and for certain purposes, for example, for medical or scientific purposes then such actions do not constitute the commission of a criminal offense of narcotics trafficking.

3. Purpose. - This element of criminal offenses of narcotics trafficking is of subjective character. Although, the lawmaker through solutions included to Criminal Code does not expressly emphasize, the purpose of criminal offenses of narcotics trafficking is the realization of material benefits.

Duly, these three elements are required to be cumulatively completed in order to be found the existence of criminal offense of narcotics trafficking and to punish an accused person for the commission of this criminal offense. Of course, the purpose has no effect on legal qualification of the offense. In this regard, when

3 The Criminal Code of the Republic of Albania, No.7895, dated 27.1.1995, provides for 3 offenses referring to narcotics trafficking (articles 283,283 / a and 284 / a). Available at: http://www.drejtesia. gov.al/wp-content/uploads/2017/11/Kodi_Penal-1.pd , whereas Criminal Code of Montenegro, Law no. 44/2017 has provided for two criminal offenses related to narcotics (Article 300 and Article 301). Available at: http://www.pravda.gov.me/ResourceManager/FileDownload.aspx?rId=256001\&rType=2 . So is the situation with the Criminal Code of the Republic of Croatia, Code no. 125/11 and 144/12 (see Articles 190 and 191). Available at: https://pravosudje.gov.hr/UserDocsImages/dokumenti/Kazneni\%20 zakon-neslu\%C5\%BEbeni\%20pro\%C4\%8Di\%C5\%A1\%C4\%87eni\%20tekst.pdf etc.

4 Criminal Code of Republic of Kosovo, Code no. 06 / L-074, Articles 267-276. Available at: https:// gzk.rks-gov.net/ActDetail.aspx?ActID=2834 . 
these combined elements include a large amount of narcotics, the Kosovo lawmaker has predicted a higher level of punishment for the perpetrator of criminal offense of narcotics trafficking.

\section{Perpetrators}

Perpetrator of a criminal offence is the person who has committed it, respectively has participated in commission of that criminal offence. Therefore, "as perpetrator of a criminal offence are considered persons which directly undertake the action of commission, but also those which by their actions incite or assist in commission of a criminal offence as well as the organizers of criminal association" (Salihu, 2008, pg.189). As perpetrator of a criminal offence of narcotics trafficking may be any person who has the age for criminal liability and is criminally liable. (meaning when he/she is aware about the importance and consequences of committed criminal offence and is able to control its behaviors) (Shala, 2013, pg. 91) who, without authorization buys or possesses for the purpose of sale or distribution or offers for sale substances that are legally designated as narcotics, respectively distributes, sells, transports, delivers and intermediates for distribution, sale and supply of narcotics, exports or imports of narcotics, or organizes, directs and finances such narcotic actions without having legal authorization.

For existence of criminal offence of narcotics trafficking is not important whether narcotics are of domestic or foreign descent. This criminal offence is committed by a person who regardless of the type or origin of narcotics, without authorization, produces, processes, buys or possesses for the purpose of sale or distribution, or offers for sale these substances, respectively distributes, sells, transports, mediates the distribution, sale and supply of narcotics, exports or imports narcotics, or arranges, directs and finances such actions with these substances without having lawful authorization. The perpetrating action of this criminal offence is defined in an alternative way (Salihu, Zhitija, Hasani, 2014, pg. 755 - 756). It consists in the production (cultivation), processing, purchase, possession and sale of narcotics; distributing, selling, transporting, supplying and mediating narcotics for the distribution, sale or supply of narcotics, the exportation and importation of narcotics or the organization, direction and financing of the abovementioned narcotics actions. Whichever of these actions constitutes the commission of criminal offences of narcotics trafficking and the reason for punishment of their perpetrators.

\section{Criminal liability}

Concerning the definition of criminal liability there are opinions which date back since the most ancient times. These opinions have included in itself two components: mind and body (Platt, Diamind, 1966, pg. 1231). Consequently, a person shall be considered criminally liable if in commission of a criminal offence possessed certain psychic qualities and if he has had a certain psychic relationship to the criminal 
offense he has committed it. In other words, one shall be considered criminally liable if in time of commission of a criminal offence has been accountable and guilty. Therefore, one shall be considered criminally liable when he/she possesses such mental qualities that make it possible to understand the importance of offence and to control his/her own behaviors (Salihu, 2008, pg. 278). However, the perpetrator of criminal offence shall be considered guilty when to the committed criminal offence has that kind of attitude or rapport which makes it possible to charge him/her with the criminal offense, respectively when it considers the criminal offence as its own, when he has committed the criminal offence by intent or negligence (Hall, 1975, pg. 205).

Therefore, any person shall be considered criminally liable if in the time of committing criminal offence of narcotic trafficking has been accountable and guilty. When it comes to guilty, it is worth emphasizing the fact that "Actions that constitute the criminal offence of narcotic trafficking are committed only by intent and in order to obtain material benefits, although the purpose is not expressly mentioned as an indispensable element of figure of this criminal offense but which is implied in itself. In any case, motives and purposes have no importance concerning effects of the legal qualification of this criminal offense (Elezi, 1999, pg. 116). In this regard, the criminal offence of narcotic trafficking cannot be committed by negligence.

\section{Manners of commission}

Criminal offence of narcotic trafficking may be committed in several manners. These committing manners of criminal offence of narcotic trafficking may result in different classifications, including but not limited to: a) production and processing without authorization for narcotics sales, b) purchases without authorization and possession without the authorization of narcotics for the purpose of sale, c) distribution, sale, transport or delivery for the purpose of distribution, sale or offer for sale of narcotics, d) unauthorized export and import of narcotics, and e) organization, direction or financing of narcotics trafficking.

According to the first criterion, the criminal offence of narcotic trafficking can be committed in two manners:

a) By producing and cultivating narcotics without having an authorization for sale.- This committing manner of the criminal offence of narcotic trafficking is conducted through undertaking through one of the following actions: production (cultivation) of narcotics for the purpose of sale and $b$ ) narcotics processing for the purpose of sale. These are considered to be alternative actions of committing the criminal offence of narcotic trafficking. This implies that each of these actions represent a special way by means of which shall be committed this criminal offence, although this committing manner of the criminal offence of narcotic trafficking exists even in case when the perpetrator undertakes (at the same time) such actions. 
b) By buying without legal authorization or possession without authorization a narcotic for the purpose of sale.-This manner of committing the criminal offence of narcotic trafficking shall be conducted through undertaking through one of the following actions: a) Purchase of narcotics for the purpose of sale, distribution or delivery for sale, and $b$ ) possession of narcotics for the purpose of sale, distribution or sale for sale. "The common thing of these two actions of committing this criminal offence is that the same are directed against the common protective object, that they are committed without authorization, they do have their common committing mean, and the consequence of criminal offence is the same, and both actions are committed only by intent (Salihu, Zhitija, Hasani, 2014, pg. 755). What distinguishes these two actions of committing trafficking are actions by means of which they are committed. In the first case the perpetrating action consists in purchase of narcotics, whereas in the second case in possession of narcotics. But in both cases the goal is common. That goals consists of sale, distribution or supply for narcotics sales.

c) By distributing, selling, transporting or dispatching for distribution, sale or offer for sale of narcotics.- This manner of committing of the criminal offence of narcotics trafficking shall be realized through undertaking one of the following actions: a) a) distribution of narcotics; ) narcotics sales, c) narcotics transport, d) mediation in distribution or sale of narcotics, and e) dispatch of narcotics for the purpose of distribution or sale or supply of narcotics sales. "It should be kept in mind that each of these actions represent a special form by means of which shall be committed the criminal offence of narcotic trafficking but this offence may consist in undertaking two or more of these actions. This situation may come to expression in cases for instance the perpetrator at the same time sells, distributes, transports or dispatches narcotics for the purpose of selling, distributing or offering for sale" (Salihu, 2009, pg. 290).

d) By exporting and importing unauthorized narcotics.- This committing manner of the criminal offence of narcotic trafficking shall be conducted through undertaking one of the following actions: a) distribution of narcotics, b) unauthorized export of narcotics, and c) importation unauthorized narcotics. In a concrete case, the criminal offence of narcotic trafficking is considered to be committed when without a relevant authorization is the transfer of drugs is outside the Kosovo border, or drugs are introduced within the Kosovo border. In a case of this form, the criminal offence of narcotic trafficking is conducted to be committed even in cases when the importation of narcotics is done for personal needs. It is sufficient to be made without having any legal authorization.

e) By organizing, directing or financing activities referring to the possession, purchase or sale of narcotics for sale in an unauthorized manner.- This committing manner of the criminal offence of narcotic trafficking shall be 
conducted through undertaking one of the following actions: a) organization actions referring to the possession, purchase and sale of unauthorized narcotics, b) the conduct of actions involving the unauthorized possession, purchase and sale of narcotics, and c) the financing of actions referring to possession, the purchase of delivery for sale of narcotics in an unauthorized manner. "The criminal offence of narcotic trafficking shall be considered to be committed by undertaking only one of these three actions. But this criminal offence is considered to be committed even if at the same time two or three actions are cumulatively undertaken. In order for this criminal offense to exist, the perpetrator should be aware that without proper authorization he is organizing, running or financing activities that are in the function of possession, purchase or delivery for sale of narcotics (Salihu, Zhitija, Hasani, 2014, pg. 767).

\section{CRIMINOLOGICAL ASPECTS OF CRIMINAL OFFENSE OF NARCOTICS TRAFFICKING}

\section{Volume, dynamics and territorial scope}

Volume, dynamics and territorial scope of a particular type of criminal offences represent an indicator through which is aimed to present the level and movement of respective criminal behaviors through years and certain regions of country or even beyond. In order to achieve this goal, in the following of this scientific paper shall be handled these category, of course related to the criminal offences of narcotic trafficking in Kosovo.

\subsection{Volume}

Handling the criminal offences of narcotics trafficking volume as its own goal has the presentation of their level of presence in country. Of course, the real presentation of this type of criminal offences presence, similar to other forms of criminality is a complex, challenging and insoluble problem. "This occurs due to the fact that the accurate volume of criminality appearing in society, regardless of formal evidence, which is almost impossible to know because it is never fully documented, is not entirely known because of the different circumstances that are present in society" (Halili, 2008, 115). Bearing in mind the fact that also to the criminal offences of narcotic trafficking are present these circumstances, then the statistical data which we do refer in relation to their volume, should be seen in these terms by all reservations, which usually are present in researched of this kind. Despite this, for purposes of this research, in the following table shall be presented the data concerning the number of submitted indictments for commission of criminal offences of narcotic trafficking (State Prosecutor's Work Reports for the years 2013 -2017) and the number of convicted persons in relation to these criminal offences 
during the period of time 2013-2017 (Statistical reports (periodic and annual) of the Kosovo Judicial Council).

Table 1. The number of indicted and convicted persons for commission of criminal offences of narcotic trafficking.

\begin{tabular}{|c|c|c|}
\hline $\begin{array}{c}\text { Period of time } \\
2013-2017\end{array}$ & $\begin{array}{c}\text { The number of indicted } \\
\text { persons }\end{array}$ & $\begin{array}{c}\text { The number of convicted } \\
\text { persons }\end{array}$ \\
\hline & 2987 & 1950 \\
\hline
\end{tabular}

According to these data during the period of time 2013-2017 in Kosovo for commission of criminal offences of narcotic trafficking have been indicted 2987 persons, of whom 1950 have been convicted. This number of convicted persons is 1037 fewer than the number of persons indicted with committing these criminal offenses, especially with their level of presence based on the perception of public opinion that exists in Kosovo. The causes of this situation probably should be sought in inefficient and quality management in relation to process of proving these criminal offenses, but without excluding other factors. Of course, the presence of the corruption phenomenon in the Kosovo judiciary (Riinvest Institute, 2013, pg.18), as well as political interferences in the country's judicial system, which are mainly reflected in cases involving in this criminal business of political figures whether directly or indirectly (Riinvest Institute, 2013, pg.18). The data used prove the fact that during the researching period of time among criminal offences of narcotic trafficking for which the basic courts of the Republic of Kosovo have imposed sentencing judgments has dominated the criminal offence of unauthorized possession of narcotics, psychotropic or analog substances which is represented by 1170 cases, and then comes the criminal offense of Unauthorized Purchase, Possession, Distribution and Sale of Narcotic, Psychotropic and Analogue Substances which is represented by 477 cases, the criminal offense of unauthorized production and processing of narcotics, psychotropic substances, analogues or utensils, narcotic equipment or drugs with 178 cases, and all other types of narcotics are represented with 125 cases. The cause of this condition should be sought at the increasing level of narcotics users and dosage distributors that may be called relatively small narcotic substances, but without excluding the influence of other factors (advanced controls of the nightclubs by the police, announcements from the responsible schools, pharmacies, citizens, etc.).

\subsection{Dynamics}

Handling the dynamic of criminal offences of narcotic trafficking aims at presenting the data concerning these criminal offences according to their level of manifestation over the years. Therefore, through this scientific paper shall be reflected the level of presence in relation to criminal offences of narcotic trafficking 
in Kosovo during the period of time 2013-2017. In fact, in the following table shall be presented the Kosovo Judicial Council data concerning the number of convicted persons for commission of these criminal offences during this period of time, by following their chronological course progress.

Table 2. The number of convicted persons for commission of criminal offences of narcotic trafficking during the period of time 2013-2017.

\begin{tabular}{|c|c|}
\hline Period of time & The number of convicted persons \\
\hline 2013 & 56 \\
\hline 2014 & 211 \\
\hline 2015 & 353 \\
\hline 2016 & 447 \\
\hline 2017 & 683 \\
\hline In total & 1950 \\
\hline
\end{tabular}

According to these data, the largest number of persons for commission of criminal offense of narcotics trafficking has been convicted in 2017 (683 perpetrators), then in 2016 (447 perpetrators) in 2015 (353 perpetrators) in 2014 ( 211 perpetrators) and in 2013 (56 perpetrators). The data used prove that from 1,950 convicted persons for commit criminal offenses of narcotics trafficking in 1845 cases have been convicted adult persons whereas in 105 cases, have been convicted minor persons. The data in this table indicates the number of persons convicted for commission of these criminal offences during the researching period has continued to grow rapidly. Such growth is noted especially in the last three years (2015, 2016 and 2017). This increase has come to expression as in cases of major perpetrators, as well as juvenile perpetrators of these criminal offenses. The causes of this situation of course are numerous and diverse. They can of course refer to the increase of cases of commission of these offenses in recent years, the established judicial priorities, increase respectively decrease of effectiveness of the courts' work over the years etc.

\subsection{Territorial scope}

Criminal offences of narcotic trafficking during the period of time 2013-2017 have marked their presence in the entire territory of Kosovo. Of course, the level of their presence in various municipalities is higher, while in other is lower. What was the territorial scope of these criminal offences within Kosovo basic courts territory for the researching period of time is best indicated from the data that shall be reflected in the following table. 
Azem Hajdari i Albulena Hajdari: The specifics of the illegal drug trafficking in Kosovo Zbornik radova Pravnog fakulteta u Splitu, god. 57, 1/2020, str. 239-261

Table 3. Territorial scope of criminal offences of narcotic trafficking

\begin{tabular}{|c|c|}
\hline Basic Courts & The number of convicted persons \\
\hline Basic Court of Prishtina & 776 \\
\hline Basic Court of Mitrovica & 76 \\
\hline Basic Court of Peja & 215 \\
\hline Basic Court of Prizren & 376 \\
\hline Basic Court of Ferizaj & 188 \\
\hline Basic Court of Gjilan & 214 \\
\hline Basic Court of Gjakova & 102 \\
\hline In total & 1950 \\
\hline
\end{tabular}

According to these data during the period 2013 - 217 for commission of criminal offenses of narcotics trafficking from the Basic Court of Prishtina have been convicted 776 persons, from the Basic Court of Prizren 376 persons, from the Basic Court of Peja 215 persons, Basic Court of Gjilan 214 persons, from the Basic Court of Ferizaj 188 persons, from the Basic Court of Gjakova 102 persons and from the Basic Court of Mitrovica 76 persons. The cause of this situation in relation to the Basic Court of Prishtina must, however, be related to the large number of cases that this court has at work, which is conditioned by the fact that it extends its activity to a territory in which it lives more than $1 / 3$ of the population of Kosovo (Kosovo Agency of Statistics, Report 2011). The territory covered by Basic Court of Pristina is populated by people of great cultural, educational, social diversity, etc., which is much less expressed in other territories of the country. This fact has determined a greater source of causes for the commission of criminal offenses of narcotics trafficking within the territory of this court. Meanwhile, the cause of such situation in relation to the Basic Court of Mitrovica should be related to the fact that this court until the beginning of 2017 has worked in halved capacities and in inappropriate environments.

\section{Kosovo-country of origin, transit or destination of narcotics}

The researching period of time (2013-2017) has been characterized by existence of a difficult and complicated economic, political and social situation, by fragile and many deficiencies of security and judicial system and of high presence of official corruption. These and other factors directly impact Kosovo to be the country of origin, transit or destination of narcotics. That Kosovo is considered to be the country of origin of narcotics indicates the data that only during the years 2013 , 2014, the Kosovo Police had submitted criminal reports for 89 cases (Kosovo Police, Annual Reports for 2013 - 2014, pg. 18 - 19), related to criminal cases of narcotics production and cultivation, and during 2009 they were discovered 33 
thousand cultivated cannabis plants in many areas of Kosovo (Free Radio Free Europe, pg. 1). The data used prove that Kosovo besides being a country of origin, is also an important node in the transit of narcotics. According to the Report on the Situation of Organized Crime and Economic Crime in Southeast Europe, Kosovo is a territory through which narcotics from Turkey or other countries (Macedonia, Albania, etc.) are transported to Central and Western European countries. The report notes the fact that Albanian criminal groups in Kosovo and Albania have become main suppliers of herbal cannabis and are supporting the Turkish heroin and Colombian drug traffickers towards EU countries. The data used prove that Kosovo besides being a country of origin, it is also an important node in the transit of narcotics. According to the Report on the Situation of Organized Crime and Economic Crime in Southeast Europe, Kosovo is a territory through which narcotics from Turkey or other countries (Macedonia, Albania, etc.) are transported to Central and Western European countries. The report notes the fact that Albanian criminal groups in Kosovo and Albania have become main suppliers of herbal cannabis and are supporting the Turkish heroin and Colombian drug traffickers towards EU countries (CAPRO Regional Project, 2006, pg. 22). Between June and December $2003,90 \mathrm{~kg}$ of heroin were confiscated, of which $38 \mathrm{~kg}$ in Kosovo, $24 \mathrm{~kg}$ in Italy and $28 \mathrm{~kg}$ in Bulgaria, quantities believed to have come through Kosovo (CAPRO Regional Project, 2006, pg. 105). Finally, Kosovo is considered to be a place of narcotics destination. This fact is evidenced by the data used, which undoubtedly prove that a significant part of narcotics entering Kosovo are distributed here. Thus, only in 2014 it was possible to seize a drug amount of $5165 \mathrm{~kg}$, a considerable part of which is estimated to have been destined for its consumers in Kosovo (Kosovo Police Report, 2014, pg. 19). This is explained by the fact that there are over 25,000 drug users in Kosovo (Center "Labyrinth",Report 2017, pg. 1).

\section{Several personal data of perpetrators}

Criminality in general, therefore also its specifics types, it cannot be explained their entire complexity without studying and analyzing also several basic personal and social characteristics of these behaviors, because criminality as a general phenomenon is manifested through the commission of concrete criminal offences (Ačimović, 1976, pg. 7 - 8). Bearing in mind this fact, in the following handling briefly shall be discussed about age, gender, educational level and social affiliation concerning trafficking perpetrators of criminal offences narcotic.

In order to handle these characteristics, I have used the data of 100 studied judgments which during the period of time 2013-2017 have been imposed by seven (7) Kosovo basic courts against perpetrators of these criminal offences. From these studied judgments it results to have been punished 158 perpetrators of criminal offences of narcotic trafficking. This approach has been necessary because such personal data concerning perpetrators published by the Kosovo Judicial Council and the Kosovo Agency of Statistics are extended to all criminal offenses, and not to specific types of criminal offenses. 


\subsection{Age}

Age is an important characteristic of criminal phenomenon that has a special importance in explaining criminal behaviors (Halili, 2008, pg. 129). Age is considered to be as one of the most important factors affecting crime tendencies (Quetelet, 1984, pg. 26). Numerous statistical data from judicial practice, as well as criminological researches data prove that perpetrators belong to persons of different ages. This fact is present to all criminal offences, and thus also to criminal offences of narcotic trafficking. The results of studying 158 perpetrators of these criminal offences prove that they are mainly adults. The age of perpetrators studied in the following table looks like this:

Table 4. Age of convicted persons for committing criminal offenses of narcotics trafficking

\begin{tabular}{|c|c|}
\hline The age of convicted persons & The number of convicted persons \\
\hline $14-18$ & 7 \\
\hline $18-28$ & 38 \\
\hline $28-38$ & 64 \\
\hline $38-48$ & 37 \\
\hline $48-58$ & 12 \\
\hline Over 58 & 00 \\
\hline In total & 158 \\
\hline
\end{tabular}

According to these data the criminal offences of narcotic trafficking to a large extent have been committed by persons of ages between 28-38 years, in 64 cases, and then come persons who belong to ages between 18-28 years in 38 cases, the persons of ages 38-48 in 37 cases and so on. These data prove that perpetrators of these criminal offenses are mainly persons belonging to new ages. Conducting the largest number of criminal offenses of narcotics trafficking by persons of the above mentioned ages is explained by the fact that persons of these ages dominate the population of Kosovo and that they constitute the most active categories of the population, unable to secure a workplace and lack of perspectives, so in various cases they seek for resolution through the commission of illegal actions, including dealing with narcotics trafficking. 


\subsection{Gender}

Also gender, similar as age presents an important characteristic of criminal phenomenon that has a certain importance in explaining criminal behaviors. Exists a general impression that criminality is a typical phenomenon of masculine gender (Halili, 2008, pg. 130). Numerous researches conducted for different forms of crimes in many world countries prove this fact (Barbaret, 2004, pg. 33 - 34). This tendency is noticed also in commission of criminal offences of narcotic trafficking. Studied judgments prove that as perpetrators of these criminal offences appear mostly males. In the following table shall be reflected the gender of 158 studied perpetrators which have been punished by Kosovo basic courts for commission of criminal offenses of narcotics trafficking.

Table 5. Gender of convicted persons for committing criminal offenses of narcotics trafficking

\begin{tabular}{|c|c|}
\hline The gender of convicted persons & The number of convicted persons \\
\hline Male & 151 \\
\hline Female & 7 \\
\hline Total & 158 \\
\hline
\end{tabular}

According to these data, male persons are the ones who dominate in commission of criminal offenses of narcotics trafficking. As it turns out, the number of male convicted persons is 151, whereas the number of female convicted persons is 7 . Such high participation of males in the commission of criminal offenses of narcotics trafficking should be sought in the most favorable treatment that they enjoy in Kosovo society, "the fact that males are traditionally more active and dominant in society, which brings a much greater risk for them to be involved in crimes etc. (Hysi, 2010, 174). Consequently, the multiple lowest level of female involvement in the commission of criminal offenses of narcotics trafficking is related to the" high level of social control of female in society (Heidensohn, 2001, 171), its different treatment in Kosovo society, the biopsy structure of female, as being more difficult to adapt to difficulties, etc.

\subsection{Educational level}

Numerous criminological researches consider education as an important factor in prevention of criminality. This fact is proven also by modest results of this paper. What is the participation degree of convicted persons in commission of criminal offences of narcotic trafficking in total of 158 studied perpetrators, based on their level of education, is best evidenced by the data that shall be reflected in the following table. 
Azem Hajdari i Albulena Hajdari: The specifics of the illegal drug trafficking in Kosovo Zbornik radova Pravnog fakulteta u Splitu, god. 57, 1/2020, str. 239-261

Table 6. Educational level of convicted persons for committing criminal offenses of narcotics trafficking

\begin{tabular}{|c|c|}
\hline Educational level of convicted persons & The number of convicted persons \\
\hline Without completing primary eduation & 28 \\
\hline Orimary education & 54 \\
\hline Secondary education & 76 \\
\hline Faculty & 00 \\
\hline In total & 158 \\
\hline
\end{tabular}

According to these data the biggest number of convicted persons for commission of criminal offences of narcotic trafficking belongs to the persons who have completed their secondary education. They among the studied perpetrators participate by 76 persons, followed by perpetrators who have completed only primary school level by 54 persons, and followed by the perpetrators without completing elementary education by 28 persons. The higher degree participation of persons who have completed their secondary education in the commission of criminal offences of narcotic trafficking it seems to be in line by the level this category of persons is represented in the overall structure of the Kosovo population (World Bank Gropu, Workplace Reports Series, pg.11.), but without excluding the lack of employment prospects and independence that this level of education provides for the new generation of Kosovo. That is the matter also concerning persons who have completed their primary education that among studied perpetrators of criminal offences of narcotic trafficking takes the second place. The studied cases prove the lack of persons who have completed superior education respectively faculties in commission of these criminal offences. This indicates that these persons, regardless of statistics of unemployment constitute a percentage of about 8\% (Ministry of Labor and Social Welfare, Annual Report 2016, pg.17), despite the difficulties they face in providing their existence, hardly decide to deal with the commission of these criminal offenses.

\subsection{Social status of perpetrator}

Numerous data from judicial practice and the researches from criminological studies attest that the biggest number of perpetrators regarding criminal offences of narcotic trafficking derive from unemployed people and those people who have difficult material situation. This fact has been proven also by modest results of this paper. In the following table shall be presented the data over social status of studied perpetrators for commission of criminal offences of narcotic trafficking in relation to the period involved in the research. 
Azem Hajdari i Albulena Hajdari: The specifics of the illegal drug trafficking in Kosovo Zbornik radova Pravnog fakulteta u Splitu, god. 57, 1/2020, str. 239-261

Table 7. Social status of convicted persons for committing criminal offenses of narcotics trafficking.

\begin{tabular}{|c|c|}
\hline Social status of convicted persons & The number of convicted persons \\
\hline Employed & 26 \\
\hline Unemployed & 132 \\
\hline In total & 158 \\
\hline
\end{tabular}

According to these data from 158 of studied perpetrators 132 of them have been unemployed. This situation is almost in accordance with the unemployment rate currently existing in Kosovo, estimated to be about 30\% ( Labor Force Survey TM1, Kosovo Agency of Statistics, pg.25), and the difficult social situation in which live about half of the country's population (37\% with only 1.42 EURO per day and $15 \%$ at about 0.93 Euro per day) (Poverty Assessment in Kosovo, Report no. 32378 - JUN, June 2005). Convincing of such high numbers of criminal offenses of narcotics trafficking by unemployed persons and with serious social conditions is explained by the difficulties these persons have in ensuring the existence of the dictated by the difficult economic situation in which the country is located and the lack of prospects of the people regarding their employment (Mustafa, Zogaj, 2009, pg. 14, Recica, 2009, pg. 35), but without excluding the impact of other factors. Based on these facts, it can be concluded that with the increase of employment rate and welfare of citizens shall come by all means to reduction of cases of committing these criminal offenses.

\section{Consequences of criminal offenses of narcotics trafficking}

Criminal offenses of narcotics trafficking cause numerous and diverse consequences. The consequences caused by these criminal offenses, in general, may be of health, social and misbehavior character (narcotics and commission of criminal offenses), etc. In Kosovo, in recent years, narcotics users are increasing in size, especially in the young population. That this is so, proves the number of over 25,000 narcotics users that are currently considered to exist in Kosovo, and the fact of year-on-year increase in the number of narcotics consumers who visit and undergo treatment in psychiatric clinics in Kosovo. Thus, while in 2011 there were 731 visits to these clinics, and 169 narcotics consumers were hospitalized, in 2012773 visits were made and 197 narcotic users were hospitalized (AMCDDA and Ministry of Internal Affairs, National Report - Kosovo 2014, pg. 23). The consequences caused by these criminal offenses of narcotics trafficking, although numerous, however, are in the first place of a health character (the morbidity and mortality of narcotics). "Hence, from the use of narcotics without medical reason and without the recommendation of the specialist doctor comes to the gradual destruction of the physical and mental health until the death of the person (Merja, 2014, pg. 1)." Consequently, five categories of diseases associated with the use of illicit drugs 
are distinguished: (a ) overdose; (b) other damages; (c) non-transmissible diseases; (d) mental health disorders; and (e) infectious diseases (Todhri, 2015, pg. 38). Overdoses (drug poisoning) occupy the major weight in the narcotics consumers' mortality. It is scientifically established that narcotics users experience an increased risk of dying (Darke, Degenhardt, Mattik, 2007, pg. 145). It is estimated that about $35 \%$ to $50 \%$ of drug injectors have experienced at least one non-fatal overdose during their lifetime(Karin, Carl, 2003, pg. 220 - 229). Narcotics harm cognitive skills, eyesight, psychomotor control, reaction time, etc. These damages have an impact on the commission of a number of criminal offenses, especially in public traffic (Erin, Shane, 2004, pg. 239 - 248). A meta-analysis of cannabis use shows that the proportion of non-fatal injuries among drivers that resulted positive for cannabis varies from 5\% to $16.9 \%$. Attempted or completed suicide is another kind of consequence that may be related to the use of illegal drugs (Paul Goldstein, 1985, pg. 15:499 -500). The negative health consequences associated with nontransmissible diseases vary depending on the type of drug used and its route of administration (Sandro, David, 2002, pg. 139 - 140). For example, chronic use of cocaine and amphetamines can lead to fatal cardiovascular consequences, while cannabis may affect pulmonary dysfunction, and physical pain is common among drug users (Wayne, Rosalie, 2003, pg. 132). National and international diagnostic systems define addiction to drugs as a mental disorder. Therefore, drug addiction syndrome is registered as part of mental health problems. A recent study concluded that $36.4 \%$ of cocaine users had signs of psychiatric disorders, personality disorders, and depression (Wanye, Rosalie, 2003, pg. 133). Insecure injection practices, insecure sex, and multiple daily injections increase the risk of being infected with infectious diseases such as: Hepatitis B (HBV), Hepatitis C (HCV) (Strathdee, Galai, Mahboobeh, Vlahov, Lisette, Kenrad, 2001, pg. 1286), and HIV infection. In women, narcotics consumption also causes physiological damage to the menstrual cycle with consequences that may result in loss of the menstrual cycle and fertility. Also, fatal complications and consequences experience newborn babies from pregnant women using narcotics(merja, 2014, pg. 1). In addition to health consequences, offenses of narcotics trafficking also cause social consequences. These consequences may have personal, family and social extent. Personal effects are numerous and diverse. Personal effects are numerous and of different kinds. They are manifested through the isolation of the perpetrators of these criminal offenses from the family and the social environment, the manifestation of family problems (eg, divorces) (Anchalee, 1993, pg. 87), the obstacles related to education, work etc. The family consequences are related to the ignorance of the family where the perpetrator is from the social environment, the degradation and destruction of the family perspective. Meanwhile, the social consequences stem from the fact that the high presence of these criminal offenses is a barrier to the investments of local and international potential investors, for global integration processes, etc., based on the fact that this organized crime activity is hurting the image of the country, and is also being used as an obstacle to visa liberalization for Kosovo citizens. "Social consequences also lie in the detriment of the state budget. This injury is mainly related to the need to increase the capacity 
of prisons, but also to the costs associated with detention or serving sentences of perpetrators of these criminal offenses (Eric, Jurg, 2004, pg. 100 - 101)."

Meanwhile, the consequences of misbehavior are those that are reflected in the increase in the number of drug addicts, and in the commission of various criminal offenses. The growing trends that are manifesting the criminal offenses of narcotics trafficking in Kosovo, as noted above, have also influenced the increase in the number of drug addicts. Although there are no accurate statistics, it is considered that this number has exceeded the figure of 25.000 people. This is a major concern because these are people who belong to the young generations, where the possibility of influencing the use of narcotics to other young people, due to the society they create in schools and neighborhoods, is more evident. "Of course, one of the biggest consequences of the criminal offenses of narcotics trafficking lies in the relatively high level of their presence in society (Kakarriqi, Ylli, Sulaj, Bino, Bani, Selfollari, 2013, pg. 117)" and of the interrelation they have with the appearance of many other types of criminal offenses. This is because the perpetrators of these criminal offenses, in most cases, are also perpetrators of criminal offenses of trafficking in women, smuggling of goods, and kidnappings and ordered killings (Finestone, pg. 79). In fact, when it comes to drug addicts, in practice, we also come across them as perpetrators of thefts, robberies, threats, bodily injuries and even killings, even of their relatives who refuse to give money for drug purchases (Dubravko, 2008, pg. $225-226)$.

\section{Criminal policy for committing criminal offenses of narcotics trafficking}

Successfully combating criminal offences of narcotic trafficking can contribute significantly by applying adequate criminal policy in the field of criminal sanctions application. "In this regard, the main role belongs to punishments imposed against criminal offences perpetrators during criminal proceedings"(Milutinoviq, 1985, pg. 258). In this case, is deemed in adequate punishments, such that are in accordance with social dangerousness degree of criminal offence and its perpetrator.

Modest results of this scientific paper prove that Kosovo basic courts during the period of time 2013-2017 for commission of criminal offences of narcotics trafficking have convicted 1950 persons. Out of this number, for commission of these criminal offences have been imposed punishments by imprisonment 682 persons with general average of one (1) year and five (5) months, punishment by fine to 570 persons, and other punishments such as supplementary punishments, alternative sentences and educational measures when it comes to juveniles have been convicted 698 persons. These data indicate that among imposed punishments against perpetrators of criminal offences of narcotics trafficking have dominated supplementary and alternative punishments, and then punishments by imprisonment and finally punishments by fine. 
It is worth it to emphasize the fact during this period of time has come to the statutory limitation of 238 cases for which indictments have been filed (Statistical reports of the Kosovo Judicial Council 2013 - 2017).

These data prove that Kosovo courts concerning perpetrators of criminal offences of narcotic trafficking have applied a relatively mitigating criminal policy and in their job is noticed a considerable work negligence.

Bearing in mind the relatively high presence degree of criminal offences of narcotic trafficking in Kosovo, and especially the major consequences this form of criminality is causing to the country and its citizens, I consider that courts is supposed to aggravate to the maximum the criminal policies as well as to give a priority to the narcotic cases, not only in the declarative terms but also in practical sense. On the contrary, is expected in upcoming years that these criminal offenses shall continue with permanent growth trends.

\section{CONCLUSION}

Modest results of this scientific paper have led me to the following conclusions:

In Kosovo during the period of time 2013-2017 criminal offenses of narcotics trafficking have marked a relatively high presence. For the commission of these criminal offenses, have been filed 2987 indictments whereas have been convicted 1950 persons. Concerning is the fact that a large number of narcotics-related crimes continue to be undetected and unhandled by authorized state organs (in 238 cases the filed indictments have been rejected due to statutory limitation of criminal prosecution). It is also worrying, that narcotics trafficking has been steadily increasing, especially in the last three years, but also a fairly balanced extent of these criminal offenses throughout the country.

Kosovo is a country of origin, as well as a country of transit and destination of narcotics. This is due to the fact that in Kosovo over the last two decades there has been a growing trend of cultivating some of the types of drugs, the country has a geographical position that makes it an important node for narcotics trafficking and about the fact that in Kosovo there are over 25,000 drug users. Perpetrators of criminal offenses of narcotics trafficking during the investigative period were mainly persons between the ages of 18 and 48, where males dominated absolutely, persons with secondary education completed and those with poor social status. The causes of this situation are numerous and varied, but mainly related to degree of their presence and activity in the society and the severe social situation that Kosovo is currently facing. Criminal policies against perpetrators of criminal offences of narcotics trafficking are considered to be very mitigating. This is due to the fact that courts during the investigative period had imposed a relatively small number of imprisonment sentences, compared to punishment by fine, alternative punishment and supplementary punishments. Of course, the average sentences by imprisonment imposed was very low (1 year and 5 months) compared with the penalties provided 
by law for the commission of these criminal offenses. Therefore, is considered necessary for this punitive policy to be aggravated if it is desired in the future to be a decrease in the level of commission of these criminal offenses.

\section{REFERENCES}

1. Ačimović M. Pravci kriminalne psihologije, Beograd, 1976.

2. Anchalee Singhanetra-Renard, "Socio-economic and political impact of production, trade and use of narcotic drugs in Thailand", draft study prepared for UNRISD and the United Nations University (1993).

3. Annual Reports for 2013 - 2014, Kosovo Police, General Directorate of Kosovo Police. Avaliable at: http://www.kosovopolice.com/sq/dokumentet-strategjike.

4. Assessment of Corruption in Kosovo, Riinvest Institute, Pristina, 2013. Available at: https://riinvestinstitute.org/uploads/files/2016/September/15/Revaluation_i_ corruption_ne_Kosove1473932044.pdf.

5. Assessment of Corruption in Kosovo, Riinvest Institute, Pristina, 2013. Available at: https://riinvestinstitute.org/uploads/files/2016/September/15/Revaluation_i_ corruption_ne_Kosove1473932044.pdf.

6. Barbaret Rosemary, Carlos Universidad, Bowling Benjamin etc., Self-Reported Juvenile Delinquency in England and Wales, the Netherlands and Spain, Helsinki, 2004. Available at: https://www.heuni.fi/material/attachments/heuni/ reports/6KkcCSCrn/43_Self-Reported_Juvenile_Delinquency_in_Eng-Wales-NethSpain.pdf.

7. Convention on Narcotic Drugs, United Nations Convention Against the Illicit Traffic of Drugs and Psychotropic Substances of 1988.

8. Criminal Code of Montenegro, Law no. 44/2017. Available at: http://www.pravda. gov.me/ResourceManager/FileDownload.aspx?rId=256001\&rType=2

9. Criminal Code of Republic of Kosovo, Code no. 06 / L-074. Available at: https://gzk. rks-gov.net/ActDetail.aspx?ActID=2834.

10. Criminal Code of the Republic of Croatia, Code no. 125/11. Available at: https://pravosudje.gov.hr/UserDocsImages/dokumenti/Kazneni\%20zakonneslu\%C5\%BEbeni\%20pro\%C4\%8Di\%C5\%A1\%C4\%87eni\%20tekst.pdf .

11. Cultivation of narcotic plants in Kosovo, Free Radio Free Europe. Available at: https://www.evropaelire.org/a/2083294.html.

12. Daly Kathleen, Chesney - Lind, Meda, Feminist and Criminology, Heinonline, 1988. Available at: http://faculty.washington.edu/matsueda/courses/517/Readings/ Daly\%20Chesney-Lind\%20Feminism\%201988.pdf.

13. Darke Shane, Degenhardt Luisa, Mattik Richard. Mortality amongst illicit drug users: epidemiology, causes and intervention. Cambridge University Press, Cambridge, 2007.

14. Demographic data by municipalities, 2011, Kosovo Agency of Statistics. Available at: http://ask.rks-gov.net/sq/agjencia-e-statistikave-te-kosoves/add-news/te-dhenatdemografike-sipas-komunave-2011. 
15. Drug-related treatment: Request for treatment and its availability, AMCDDA and Ministry of Internal Affairs, National Report - Kosovo 201. Available at: http://www. emcdda.europa.eu/system/files/publications/847/National_Report_Kosovo_2014_ Alb_485288.pdf.

16. Dubravko Klarić, Današnji trendovi kriminala u vei sa zloporabom droga i važne karakteristike kriminalističko - metodičkog pristupa u suzbianju, Polic. sigur, godina 17. (2008), Zagreb, No. 3-4. Available at: https://hrcak.srce.hr/file/117831.

17. Dundović Darko, Ilegalni promet i trgovina opojnim drogama, Hrvatski ljetopis za kazneno pravo i praksu, Vol. 5, Br.2, Zagreb, 1998. Available at: http://www.darkodundovic.from.hr/docs/ilegalni_prometitrgopdrog.pdf .

18. Elezi Ismet, Criminal Law of the Republic of Albania, Special Part II, ALBIN, Titana, 1999.

19. Eric Jensen, Jurg Gerber, Clayton Mosher, Social Consequences of the War on Drugs: the Legacy of Failed Policy, Criminal Justice Policy Review, Vol.15(1), 2004. Available at: https://www.researchgate.net/publication/249720341_Social_ Consequences_of_the_War_on_Drugs_the_Legacy_of_Failed_Policy.

20. Erin Kelly, Shane Darke, Drug use driving, Epidemiology, impairment, risk factors and risk perceptions, Drug and Alcohol Review, University of New South Wales, Sydney, 2004.

21. Finestone Harold, Narcotics and criminality, Law and Contemporary Problems. Available at: https://scholarship.law.duke.edu/cgi/viewcontent. cgi ?article $=2705 \&$ context $=$ lcp.

22. Halili Ragip. Criminology, University of Prishtina, Pristina, 2008.

23. Hall Jones, Studies in jurisprudence an criminal theory 271-72 (1958);

24. Heidensohn Frances, Research on Women in the Criminal Justice System and Transnational Crime, HEUNI, Helsinki, 2001.Avilable at: https://www.heuni.fi/ material/attachments/heuni/reports/6KjPF9f7n/Women_in_CJS.pdf.

25. Hysi Vasilika, Criminology, Tirana, University of Tirana, 2010.

26. International Convention of 1912 (The Hague), Geneva Conventions of 1925, 1931 and 1936, 1961.

27. International Journal of Offender Therapy and Comparative Criminology, 56 (I), SAGE. Available at: https://www.researchgate.net/publication/49653959_Chinese_ Narcotics_Trafficking_A_Preliminary_Report.

28. Kaicheng Huang, Jianhong Liu, Ruohui Zhao, Gouling Zhao, Paul C. Friday, Chinese Narcotics Trafficking : A Preliminary Report.

29. Kajtazi Ridvan, The role of police in combating narcotic criminality, Balkan Journal of Interdisciplinary Research, Special Issue No. 1/201. Available at: https:// www.researchgate.net/publication/314187828_Roli_i_Policise_se_Kosoves_ne_ luftimin_e_narko-criminality.

30. Kakarriqi Eduard, Ylli Alban, Sulaj Zihni, Bino Silva, Bani Roland, Sokol Selfollari, Drug situation: New developments, networks and detailed information on specific issues, Annual Report Albania 2013, AMCDDA. Available at: http://www. 
emcdda.europa.eu/system/files/publications/806/National_Report_Albania_2013_ Alb_483967.pdf.

31. Karin Tobin and Carl Latkin, The relationship between depressive symptoms and nonfatal overdose among a sample of drug users in Baltimore, Journal of Urban Health, Maryland., 2003.

32. Kmbovski Vlado, Commentary on the Criminal Code of the Republic of Macedonia, Skopje, 2011.

33. Labor and Employment, Ministry of Labor and Social Welfare, Annual Report 2016. Available at: file: /// C: /Users/Hajdari/Downloads/Puna\%20dhe\%20Punesimi, $\% 20$ 2016.pdf .

34. Labor Force Survey TM1, Kosovo Agency of Statistics. Available at: http://ask.rksgov.net/media/4103/anketa-e-fuqis\%C3\%AB-pun\%C3\%ABtore-tm1-2018.pdf.

35. Merja Dine, Narcotics (Drugs), Health Damage and Political Enlightenment, Telegraph, August 18, 2014. Available at: http://telegraf.al/aktualitet/prof-as-dr-dinemerja-lendet-narkotike-drogat-demet-shendetësi-dhe-sensibilizimi-politik/.

36. Merja Dine, Narcotics (Drugs), Health Damage and Political Enlightenment, Telegraph, August 18, 2014. Available at: http://telegraf.al/aktualitet/prof-as-dr-dinemerja-lendet-narkotike-drogat-demet-shendetësi-dhe-sensibilizimi-politik/.

37. Milutinovic Milan. Criminal Policy, University of Pristina, Pristina, 1985.

38. Mustafa Muhamet, Zogaj Alban, Kosovo Challenges for Economic Sustainability, Thesis Kosova, no. 1, 2009. Available at: https://aab-edu.net/assets/ uploads/2016/10/01-2009-03-Muhamet-Mustafa-dhe-Alban-Zogaj.pdf

39. Paul Goldstein, The drugs/violence nexus: a tripartite conceptual framework. Journal of Drug, Issues 15(4), 1985. Available at: https://www.researchgate.net/ publication/279892146_The_DrugsViolence_Nexus_A_Tripartite_Conceptual_ Framework.

40. Perkins, Criminal law 663-71 (1957); Snyder, An introduction to criminal justice 138-49 (-95-3) Orvill C. Criminal responsibility, Available at: https://scholarship.law. duke.edu/cgi/viewcontent.cgi?article $=1802 \&$ context $=\mathrm{dlj}$.

41. Platt Anthony, Diamind Bernard, The Origins of the "Right and Wrong" Test of Criminal Responsibility and Its Subsequent Development in the United States: An Historical, California Law Review, Volume 54, Issues 3/1966. Available at: https:// scholarship.law.berkeley.edu/cgi/viewcontent.cgi?article=2914\&context=california lawreview.

42. Poverty Assessment in Kosovo, Report no. 32378 - JUN, June 2005, World Bank. Available at: http://siteresources.worldbank.org/INTKOSOVO/Data\%20and\%20 Reference/20676217/Poverty_Assesment_shqip.pdf.

43. Pragnesh Parmar, Gunvanti B. Rathod, Sangita Rathod, Ashish Parikh, Drug abuse and Illicit Drug Trafficking Vis- A - Vis Human Life - A Review, Premisa Med Agent Vol: 101, Issue 2/2012. Available at: https://www.scitechnol.com/drug-abuseand-illicit-drugtrafficking-visavis-human-life-a-review-fWeN.php?article_id=2629. 
44. QueteletAdolphe.Onthedevelopmentof thepropensity tocrime,AndersonPublishingCo Cincinnati, OH 45202, New York, United States of America, 1984. Available at: https://www.ncjrs.gov/App/Publications/abstract.aspx?ID=94009.

45. Recica Fetah, Structural features of the Kosovo economy, Thesis Kosova, no. 1, 2009, Available at: https://aab-edu.net/assets/uploads/2016/10/01-2009-04-Fetah-Recica. pdf.

46. Report of the Medico-Psychotherapeutic Center "Labyrinth", Prishtina, 2017, Telegrafi.com. Available at: https://telegrafi.com/rreth-25-mije-perdorues-tedrogave-ne-kosove/.

47. Report on the amount of seized drugs for 2014, Kosovo Police, 2014.

48. Report on the Situation of Organized Crime and Economic Crime in South East Europe, CAPRO Regional Project, Concil of Europe, Strasbourg, 2006. Available at: https://rm.coe.int/16806ef3d4.

49. Salihu Ismet (I), Criminal Law, Special Part, FAMA College, Prishtina, 2009.

50. Salihu Ismet (II). Criminal Law, General Part, University of Pristina, Pristina, 2008.

51. Salihu Ismet, Zhitija Hilmi, Hasani Fejzullah, Criminal Code of the Republic of Kosovo- Commentary, GIZ, Legal Reform Project in Kosovo, Pristina, 2014.

52. Sandro Galea, David Vlahov, Social determinants and the health of drug users: socioeconomic status, homelessness, and incarceration, Public Health Reports 2002; v. 117 (Suppl 1). Available at: https://www.ncbi.nlm.nih.gov/pmc/articles/ PMC1913691/.

53. Shala Afrim. Introduction to Criminal Law, College "GJILANI", Gjilan, 2013.

54. State Prosecutor's Work Reports for the years 2013 - 2017. Available at: http://www. kpk-rks.org/raporte/222/2017-raportetv/222.

55. Statistical reports (periodic and annual) of the Kosovo Judicial Council on the manner of solving judicial cases and judgments of the Basic Courts for the period 2013 - 2017. Available at: http://www.gjyqesori-rks.org/en/job/list.

56. Statistical reports (periodic and annual) of the Kosovo Judicial Council on the manner of resolving judicial cases for the period of time 2013 - 2017.

57. Strathdee Steffanie, Galai Noya, Mahboobeh Sefaeian, Vlahov David, Lisette Jacobson, Kenrad Nelson. Sex differences in risk factors for HIV Seroconversion Among Injection Drug Users, Arch Intern Med, Vol /161/2001.

58. The Criminal Code of the Republic of Albania, No.7895. Available at: http://www. drejtesia.gov.al/wp-content/uploads/2017/11/Kodi_Penal-1.pdf.

59. The Criminal Convention transnational agreement called the Palermo Convention of 2000 .

60. Todhri Fiona, Youth Risk Risk Dynamics, Drugs and Social Services Opportunity Offered, $\mathrm{PhD} \mathrm{PhD}$ in the University of Tirana, 2015. Available at: http://www. doktoratura.unitir.edu.al/wp-content/uploads/2013/06/Documentation-FionaRegistry-Faculteti-i-Shkencave-Sociale-Departamenti-i-Punes-Sociale .pdf.

61. Wayne Hall, Rosalie Pacula, Cannabis use and dependence, Public health and public policy. Cambridge University Press, Cambridge, 2003. 
62. Workplaces Diagnosis in Kosovo, WorldBank Gropu, Workplace Reports Series, pg.11. Available at: http://documents.worldbank.org/curated/en/519991508764269649/pdf/ ACS21442-WP-ALBANIAN-93p-KOSOVO-Jobs-Diagnostic-Final-for-printingALB.pdf.

\section{TRGOVINA NARKOTICIMA NA KOSOVU}

Predmet ovog znanstvenog rada su kaznena djela trgovine narkoticima u Republici Kosovo. Prema podacima trgovina narkoticima predstavlja zabrinjavajući fenomen što se povezuje s relativno visokim stupnjem njihove prisutnosti u kosovskom društvu. Istraživanje osvjetljava činjenicu da je Kosovo važna karika za međunarodnu trgovinu drogom. Sve to, zbog zemljopisnog položaja zemlje, zbog činjenice da na Kosovu ima preko 25.000 registriranih korisnika droga, ali isto tako i zbog činjenice da je u posljednja dva desetljeća prisutan trend kontinuiranog rasta uzgoja droga. Kaznena djela trgovine narkoticima pokazuju brojne individualne, obiteljske i socijalne posljedice. Taj fenomen također šteti slici Kosova u međunarodnim okvirima. Kosovo se suočava s brojnim izazovima i problemima u borbi protiv kriminala, posebno s onima koji se odnose na narkotike. U ovom su radu naznačene aktivnosti kosovskih sudova u borbi protiv kaznenih djela trgovine opojnim drogama; također se predlažu mjere promicanja učinkovitosti sudova u borbi protiv pojave. Za pripremu ovog znanstvenog rada korištene su pravne, komparativne, opisne, anketne i statističke metode.

Ključne riječi: trgovina ljudima, opojna droga, sud, počinitelj, kazna 